\title{
Design Prototype Meja Penjaja Ikan dan Daging
}

\section{${ }^{1}$ Nur Ihwan Safutra, ${ }^{2}$ Muhammad Ihsan Khairullah}

${ }^{12}$ Program Studi Teknik Industri, Universitas Muslim Indonesia, Jl.Urip Sumoharjo Km.04 Makassar, Indonesia, 90231

Correspondence: Nur Ihwan Safutra (nurihwansaputra44@gmail.com)

(085216360105/082294960133)

Received: 300721 - Revised: 090821 - Accepted: 100921 - Published: 150921

\begin{abstract}
Abstrak. Di Indonesia, 70 \% konsumen daging berasal dari pasar tradisional, sementara sisanya hanya 30 $\%$ dari Supermarket (Haq et al., 2015). Aspek higiene dan sanitasi tempat - tempat umum (Public Place Sanitation) merupakan salah satu aspek yang harus diperhatikan. Tantangan yang dihadapi sekarang adalah adanya pandemi ergonomi Covid-19 yang melanda hampir seluruh dunia, menghindari penyebaran virus antara produsen, pengecer dan konsumen merupakan isu penitng mengenai keamanan pangan. Pada penelitian kali ini, kami mendesain ulang meja penjaja ikan untuk meningkatkan kualitas higienes dan sanitasi menggunakan metode Ergonomic Function Deployment (EFD). Dengan desain meja ini, para penjaja ikan dan daging di pasar tradisional memiliki kemudahan dalam mengelola sampah sisa pemotongan dan keran yang menjaga kehegienitasan dan sanitasi dagangan maupun pedagang.
\end{abstract}

Kata kunci: Ergonomi, kehigienitasan, Sanitasi, Meja Penjaja Ikan \& Daging, Design Prototype

Citation Format: Safutra, N.I., Khairullah, M.I. (2021). Design Prototype Meja Penjaja Ikan dan Daging. Prosiding Seminar Nasional Abdimas Ma Chung (SENAM), 2021, 33-43 


\section{PENDAHULUAN}

Makanan yang mengandung karbohidrat, lemak protein, vitamin, mineral dan air serta tidak mengandung bahan berbahaya didalamnya yang dapat merusak kesehatan sangat dibutuhkan (Hermin Nugraheni,Tri Wiyatini, 2018). Salah satunya dengan mengkonsumsi ikan dan makanan laut dapat memberi efek positif seperti sumber protein, penurunan risiko kematian jantung mendadak, dan lain-lain (Morales \& Higuchi, 2018). Selain ikan, bahan pangan yang di dalamnya terkandung zat gizi makro dan mikro yang cukup lengkap adalah daging, diantaranya protein, lemak, mineral serta zat lainnya yang sangat penting bagi tubuh (Çelik et al., 2018).

Di Indonesia, $70 \%$ konsumen daging berasal dari pasar tradisional. sementara sisanya hanya $30 \%$ dari supermarket (Haq et al., 2015). Artinya daya minat belanja masyarakat lebih cenderung ke pasar tradisional. Aspek higienis dan sanitasi tempat-tempat umum (Public Place) merupakan salah satu aspek yang harus diperhatikan (Anggraeni \& Aslamiyah, 2018). Indikator yang dipakai oleh Enviromental Performance Index (EPI) adalah 32 indikator, hal ini menunjukkan bahwa perkembangan tuntutan zaman salah satunya sanitasi. Indonesia berada di peringkat ke-116 dari 180 negara yang diukur dari 32 indikator tersebut (Hsu, 2016).

Sanitasi dan higienis sangat mempengaruhi keamanan pangan yang sudah diatur dalam Undang-Undang (UU) tentang pangan dan UU tentang Kesehatan (Lestari, 2020). Peraturan pemerintah Nomor 28 tahun 2004 tentang keamanan, mutu dan gizi pangan merupakan standar keamanan pangan yang isinya berbunyi : Setiap orang yang memproduksi dan memperdagangkan pangan yang dengan sengaja tidak memenuhi standar kemanan pangan dipidana dengan pidana penjara paling lama 2 (dua) tahun atau denda paling banyak Rp. 4.000.000.000,00 (Empat Miliar Rupiah) (Nurcahyo, 2018).

Tantangan yang dihadapi sekarang adalah adanya pandemi covid -19 yang melanda hampir seluruh dunia, menghindari penyebaran virus antara produsen,pengecer dan konsumen merupakan isu penting mengenai keamanan pangan (Mcewen, Craig A., 2017). Salah satu pangan yang sensitif akan kemanan atau kebersihannya adalah ikan dan daging. Meja penjaja ikan dan daging yang kurang higienis sangat berpengaruh pada kesegaran ikan dan daging. Terlebih lagi di masa pandemi ini dibutuhkan meja penjaja ikan yang memenuhi standar protokol kesehatan yang ditetapkan oleh pemerintah.

Kami mendesain ulang meja penjaja ikan untuk meningkatkan kualitas higienis dan sanitasi menggunakan metode Ergonomic Function Deployment (EFD) dengan 
menggunakan bahan stainless steel 304 antikarat. Dimana meja yang telah digunakan di kalangan masyarakat khususnya pedagang makanan basah di pasar tradisional masih memiliki kekurangan seperti tempat pencuci tangan, aliran air bersih untuk membersihkan olahan makanan serta alat pengolahan makanan. Kemudian nilai yang harus dikeluarkan oleh para pedagang untuk memulai usaha sangat besar tetapi tidak sebanding dengan fasilitas yang didapatkan di pasar tradisional.

\section{METODE PELAKSANAAN}

A. Objek Penelitian

Objek penelitian ini adalah pasar tradisional Antang Kota Makassar, Dimana pengambilan sampel responden dilakukan terhadap pedagang ikan dan daging Pasar Tradisional Antang

B. Jenis Data

Data yang digunakan dalam penelitian ini adalah data primer yang diperoleh langsung dari objek lapangan. Data tersebut antara lain keinginan konsumen terhadap re-design meja penjaja ikan dan daging serta data perilaku hygiene pedagang di pasar Tradisional Antang.

Jumlah subjek penelitian ini adalah 30 orang pada setiap kuisioner yang dibagikan. Kuisioner tahap akhir, digunakan untuk mengetahui tingkat kepentingan dan tingkat kepuasan mengenai meja penjaja ikan dan daging. Untuk menentukan tingkat kepentingan konsumen, kuesioner ini menggunakan skala likert yang dimodifikasikan sebagai berikut :

$\begin{array}{lll}\text { 1.Sangat Setuju } & \text { (SS) } & \text { Diberi bobot } 1 \\ \text { 2.Setuju } & \text { (S) } & \text { Diberi bobot } 2 \\ \text { 3.Cukup Setuju } & \text { (CS) } & \text { Diberi bobot } 3 \\ \text { 4.Tidak Setuju } & \text { (TS) } & \text { Diberi bobot } 4\end{array}$

C. Metode Pengumpulan Data

Pengumpulan data dilakukan menggunakan metode survei dengan menyebar kuesioner. Subyek penelitian ditentukan berdasar metode Purposive Sampling dengan kriteria responden adalah pedagang ikan dan daging pasar Tradisional Antang.

1. Pengumpulan Ergonomic Function Deployment 
Ergonomic Function Deployment (EFD) merupakan metode yang memudahkan dalam proses perancangan. Metode ini merupakan menghubungkan kebutuhan atau keinginan konsumen dengan aspek ergonomi produk. Hubungan ini akan melengkapi bentuk matrik House Of Quality yang juga menterjemahkan ke dalam aspek-aspek ergonomi yang diinginkan. Matrik House Of Ergonomic dalam penelitian ini metode disempurnakan dengan pendekatan antropometri.

\section{Langkah-Langkah EFD}

1. Identifikasi atribut produk

2. Desain Kuisioner

3. Pembentukan House Of Ergonomic

D. Metode Analisis Data

Penelitian ini mengggunakan analisis statistic nonparametric karena data dalam penelitian ini berbentuk jenjang atau ranking (ordinal).

E. Diagram Alir Penelitian

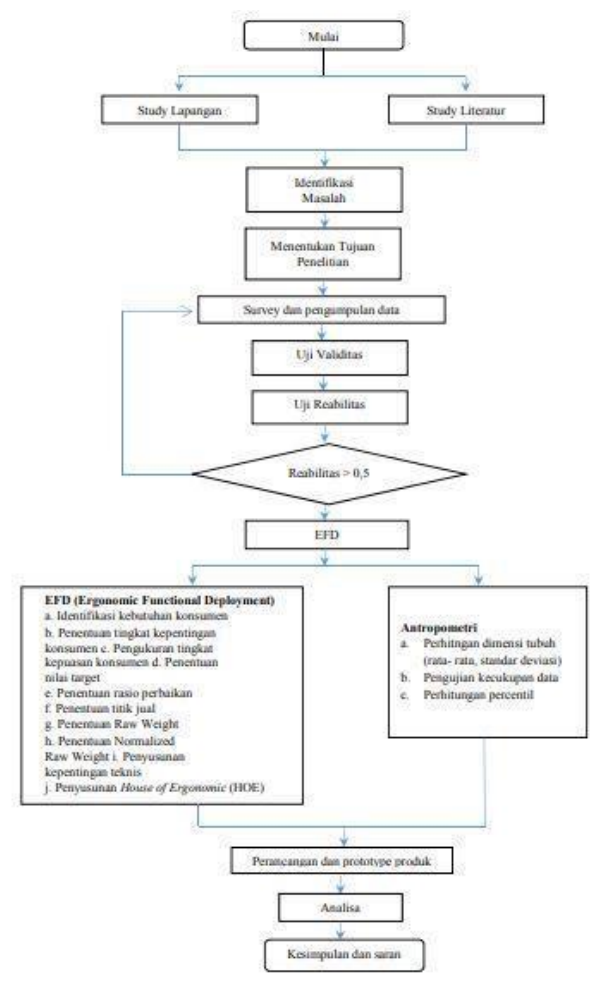

Gambar 1. Diagram Alir Penelitian

\section{HASIL DAN PEMBAHASAN}

A. Pengolahan Data Ergonomic Function Deployment (EFD) 
EFD merupakan suatu pengembangan dari Quality Function Deployment (QFD) yaitu menambahkan hubungan baru antara keinginan konsumen dengan aspek ergonomi produk yang akan dirancang. Hubungan ini untuk melengkapi bentuk matriks House Of Ergonomic yang diterjemahkan kedalam aspek-aspek ergonomi yang diinginkan. Atribut produk yang digunakan diturunkan melalui aspek ergonomi yang terdiri dari singkatan ENASE yaitu Efektif, Nyaman, Aman, Sehat dan Efisien.

1. Kebutuhan Konsumen

Tabel 1. Daftar Pertanyaan

\begin{tabular}{|lll}
\hline Variabel & Atribut & Pernyataan \\
efektif & Fungsional & Terdapat Fasilitas hygiene yang lengka \\
Nyaman & Ukuran & $\begin{array}{l}\text { Memiliki Kapasitas Maksimal } \\
\text { Desain Produk yang ergonomis }\end{array}$ \\
& & $\begin{array}{l}\text { Dimensi sesuai dengan dimensi tubuh } \\
\text { operator }\end{array}$ \\
Aman & Resiko kerja & Aman saat digunakan \\
sehat & Bahan makanan & Mengurangi timbulnya resiko kerja \\
efisien & ekonomis & Marga produk terjangkau \\
perawatan & perawatan & Mudah dalam perawatan \\
& Bahan Baku & Bahan kuat dan awet
\end{tabular}

\section{Penyusunan House of Ergonomic (HoE)}

Penyusunan matriks adalah penelitian pasar dan perancangan strategi yang dilakukan pada saat melakukan perancangan produk yang akan dibuat.

\section{Data Antropometri}

Data antropometri digunakan untuk menentukan ukuran, bentuk dan dimensi produk yang akan dibuat untuk menyesuaikan fisik pengguna. Data antropometri yang digunkan adalah tinggi siku (TS), Tinggi Popliteal (TP), Tinggi Lutut (TL), rentang tangan ke samping (RTs), rentang tangan ke depan (RTd), dan panjang lengan bawah (PLb). Data dapat dilihat pada tabel 2. 


\begin{tabular}{|c|c|c|c|c|c|}
\hline \multirow{3}{*}{ No } & \multirow{3}{*}{ Dimensi } & \multicolumn{3}{|c|}{ Data Antropometri } & \multirow{3}{*}{$\mathrm{SD}$} \\
\hline & & \multicolumn{3}{|c|}{ Persentil } & \\
\hline & & 5 & 50 & 95 & \\
\hline 1 & Tinggi Siku & 90,73 & 101,51 & 112,29 & 6,55 \\
\hline 2 & Tinggi polipteal & 31,27 & 39,89 & 50,57 & 4,25 \\
\hline 3 & Tinggi lutut & 39,2 & 49,48 & 59,75 & 6,25 \\
\hline 4 & $\begin{array}{c}\text { Rentang tangan ke } \\
\text { samping }\end{array}$ & 141,51 & 162,96 & 180,4 & 10,6 \\
\hline 5 & $\begin{array}{c}\text { Rentang tangan ke } \\
\text { depan }\end{array}$ & 62,58 & 72,37 & 82,16 & 5,95 \\
\hline 6 & $\begin{array}{c}\text { Panjang Lengan } \\
\text { bawah }\end{array}$ & 25,92 & 35,93 & 53,15 & 8,28 \\
\hline
\end{tabular}

Dari Tabel 2 untuk dimensi tinggi siku diperoleh nilai untuk setiap dimensi. Dalam penelitian ini yang akan digunakan adalah persentil 50, dimana persentil 50 mewakili ukuran rata-rata tubuh manusia.

1. Perancangan Produk

Dalam proses perancangan terdapat beberapa tahap. Hasil dari perancangan ini adalah hasil rancangan akhir yang dibuat dalam bentuk gambar. Berikut ini adalah tahapan perancangan produk meja penjaja ikan sebagai meja yang ergonomis.

a. Perancangan desain

Perancangan desain dilakukan dengan mempertimbangkan kebutuhan konsumen, target spesifikasi, dan data antropometri. Berikut ini adalah penentuan dimensi produk yang dirancang.

1. Tinggi Meja Penjaja

Ukuran tinggi meja penjaja yang digunakan berdasarkan nilai tinggi siku persentil 0 yaitu 101.51 dengan allowance $3 \mathrm{~cm}$, maka nilainya menjadi $104,51 \mathrm{~cm}$. Tetapi, disesuaikan dengan ukuran panjang display penjualan yang sudah ada dipasar yaitu $104,50 \mathrm{~cm}$.

2. Lebar Meja

Menggunakan data rentang kedepan dengan memakai persentil 50 menjadi 72,37 dengan ditambah allowance $3 \mathrm{~cm}$ dan ketebalan meja 5 $\mathrm{cm}$, sehingga lebar meja adalah $80,35 \mathrm{~cm}$. 
3. Panjang Meja

Menggunakan ukuran yaitu meliputi rentang tangan ke samping dengan persentil 50, yaitu sebesar 162,96 cm. Tetapi, disesuaikan dengan ukuran panjang display penjualan yang sudah ada dipasar yaitu $148,30 \mathrm{~cm}$.

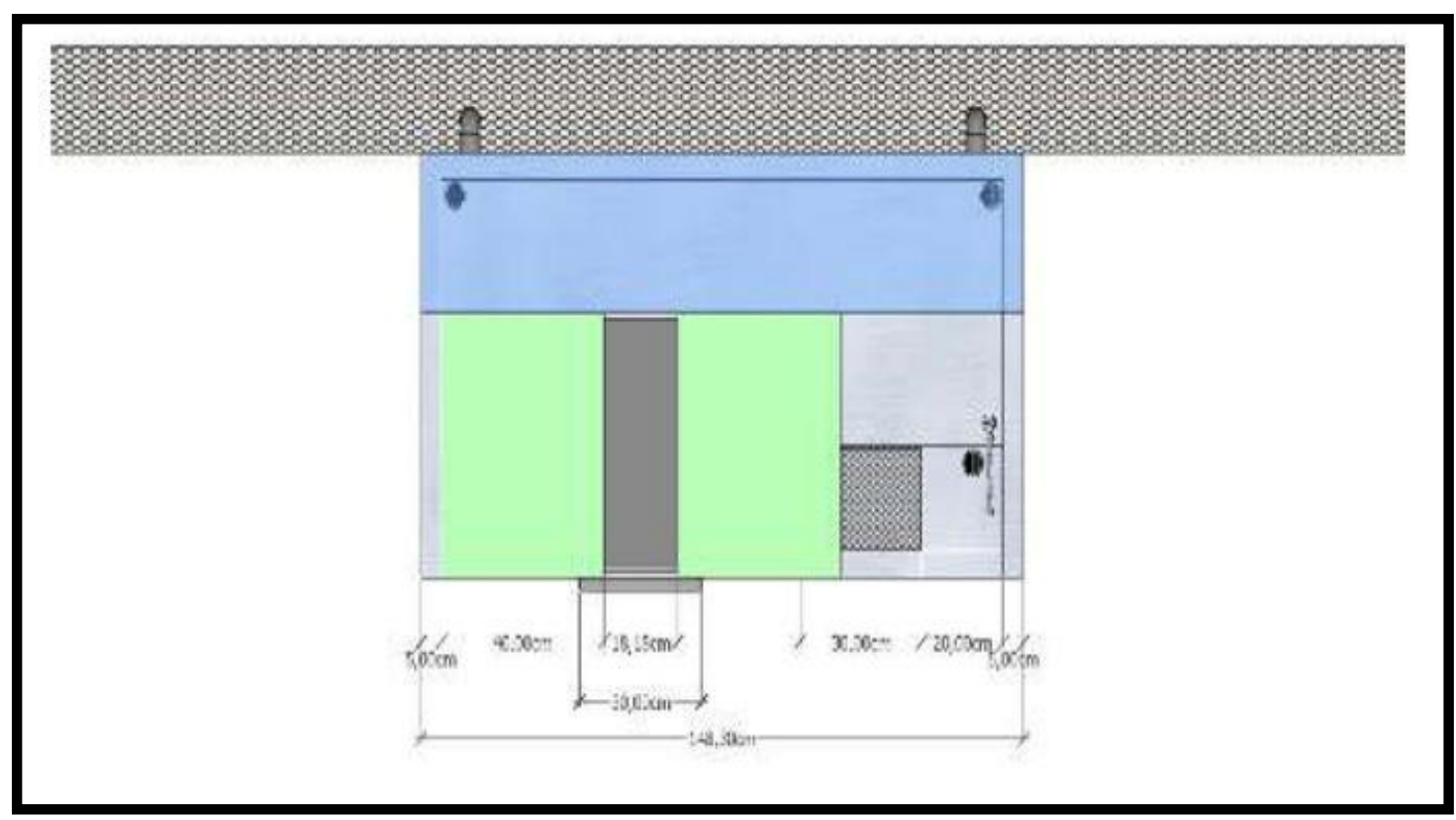

Gambar 2. Tampak Atas

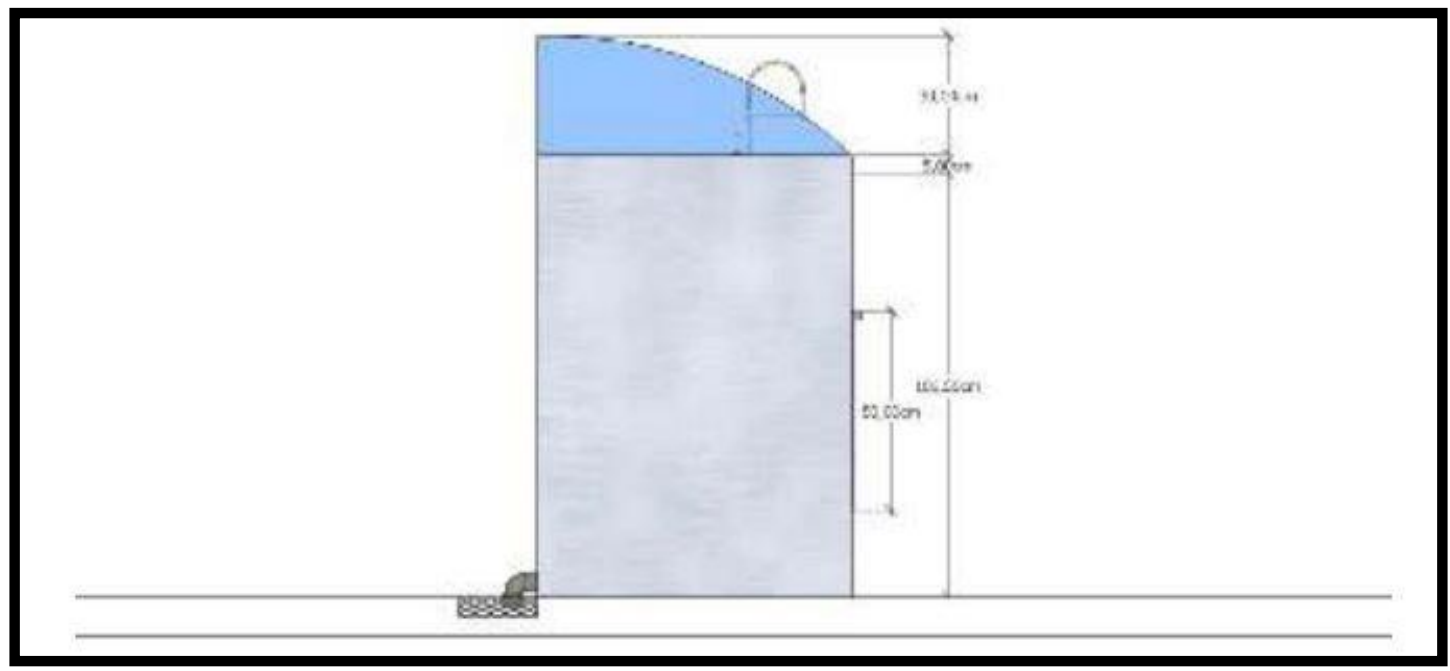

Gambar 3. Tampak Samping 


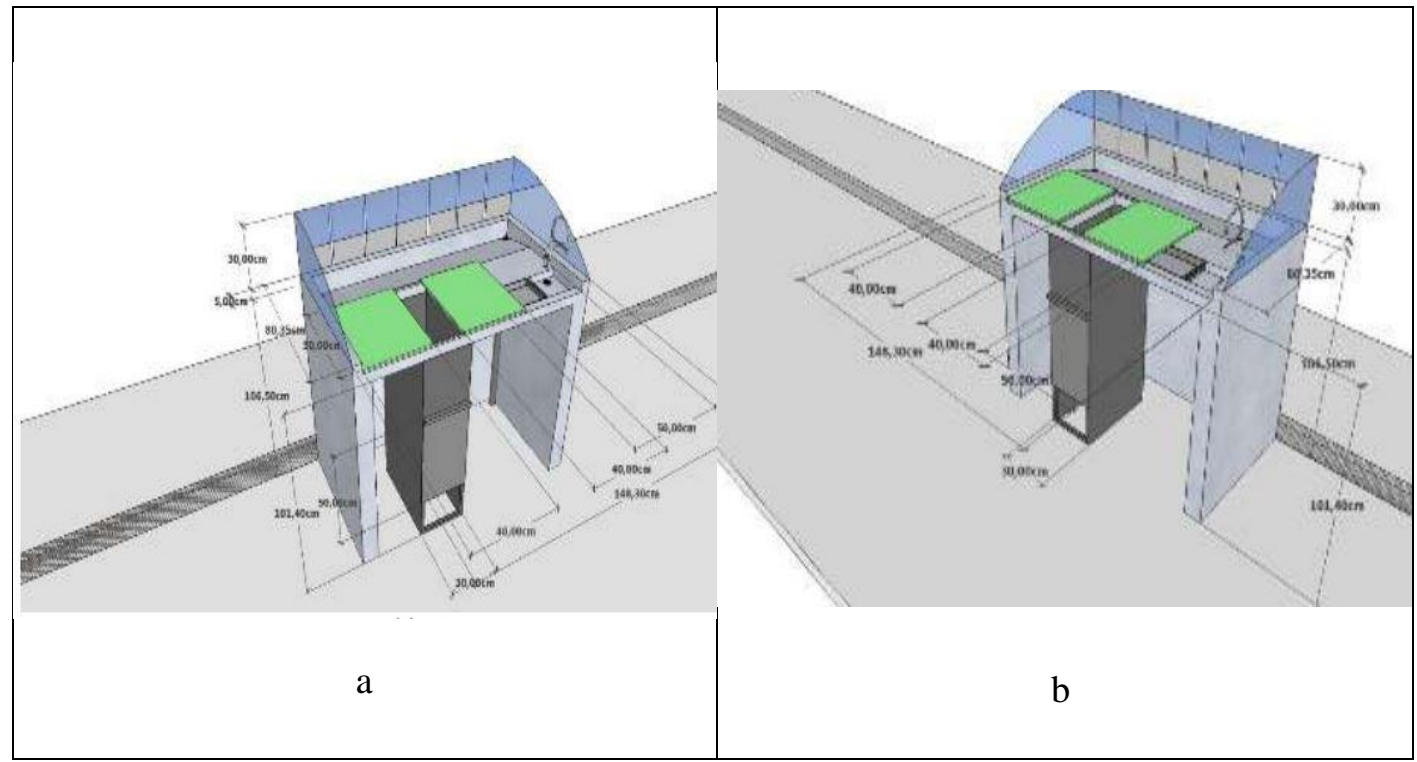

Gambar 4. Tampak 3 Dimensi

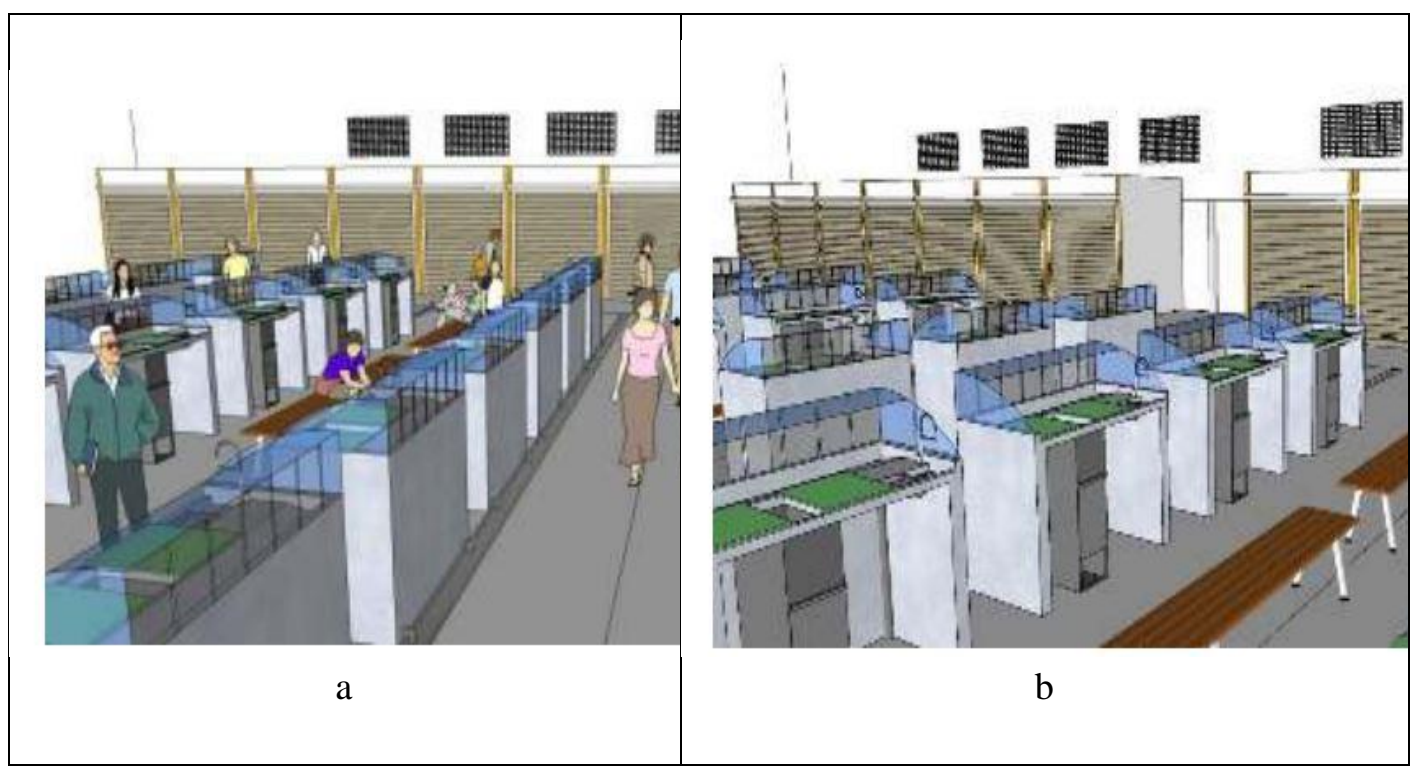

Gambar 5. Bentuk Design Pasar

5. Analisa kebutuhan Bahan dan Biaya

Tabel 3. Kebutuhan bahan dan biaya

\begin{tabular}{|cccccc|}
\hline No & Bahan & Satuan Bahan & Kebutuhan & \multicolumn{2}{c|}{ Harga } \\
& & & Bahan & Satuan & Total \\
1 & $\begin{array}{l}\text { Stainless } \\
\text { Steel 304 }\end{array}$ & $23,48 \mathrm{~kg}$ & $1 \mathrm{~mm}$ & Rp. 1. 103.475 & Rp. 1.103.475 \\
\hline
\end{tabular}




\begin{tabular}{|c|c|c|c|c|c|}
\hline \multirow{2}{*}{ No } & \multirow{2}{*}{ Bahan } & \multirow{2}{*}{ Satuan Bahan } & Kebutuhan & \multicolumn{2}{|c|}{ Harga } \\
\hline & & & Bahan & Satuan & Total \\
\hline \multirow[t]{2}{*}{2} & Stainless & $14,09 \mathrm{~kg}$ & $0,6 \mathrm{~mm}$ & Rp. 662.085 & Rp. 662.085 \\
\hline & Steel 304 & & & & \\
\hline \multirow[t]{2}{*}{3} & Besi & $30 \times 30 \times$ & 1 batang & Rp. 87.360 & Rp. 87.360 \\
\hline & Hollow & $1,44 \mathrm{~mm}$ & & & \\
\hline 4 & Keran Air & & $1 \mathrm{pcs}$ & Rp. 250.000 & Rp. 250.000 \\
\hline 5 & Pipa Wavin & $3 / 4$ inch & 1 batang & Rp. 25.000 & Rp. 25.000 \\
\hline 6 & L bow & $3 / 4$ inch & 4 buah & Rp. 6.000 & Rp. 24.000 \\
\hline & & Total & & & Rp. 2. 151.920 \\
\hline
\end{tabular}

Dari tabel diatas dapat dilihat perhitungan harga kebutuhan bahan dan kebutuhan biaya meja penjaja ikan dan daging yang ergonomis sebesar Rp. 2.151.920 yang dibulatkan menjadi Rp. 2.152.000.

\section{KESIMPULAN}

Hasil Penelitian ini dapat disimpulkan sebagai berikut :

1. Berdasarkan kuisioner pengukuran sikap higienis dan sanitasi di pasar Tradisional Antang Kota Makassar dalam pengembangan meja penjaja ikan dan daging, pedagang menginginkan adanya desain yang dapat mengakomodir beberapa kebutuhan tentang hygiene dan sanitasi. Tidak hanya sebatas memberikan tempat untuk penjaja ikan dan daging tersebut, karena dengan adanya partisipasi mereka dalam pengelolaan - pengelolaan pasar tersebut dalam bentuk kelembagaan sehingga mereka akan memiliki rasa tanggung jawab untuk lebih menjaga fasilitas pasar.

2. Parameter penyelesaian masalah yang didapatkan melalui proses identifikasi dengan Ergonomic Function Deployment dilanjutkan dengan perancangan desain meja penjaja ikan dan daging, dimana dalam perbaikan desain menghasilkan perbaikan sebagai berikut :

a. Adanya perubahan desain lama ke desain meja penjaja ikan dan daging yang baru dengan melibatkan para pedagang. 
b. Dari pengolahan model Ergonomic Function Deployment, variable yang menjadi prioritas perancangan produk yaitu ukuran meja 148,30 cm x 80,35 $\mathrm{cm} \times 106,50 \mathrm{~cm}$, ukuran meja disesuaikan dengan antropometri tubuh manusia dengan dimensi sama dengan ukuran meja, terdapat area khusus memotong, membersihkan dan membuang limbah dengan ukuran area memotong $50 \mathrm{~cm}$ x $40 \mathrm{~cm}$, area membersihkan $50 \mathrm{~cm}$ x $30 \mathrm{~cm}$, tempat sampah $50 \mathrm{~cm}$ x $30 \mathrm{~cm}$ dan pipa pembuangan 3/4, terdapat area khusus menyajikan dengan ukuran $148,30 \mathrm{~cm} \times 75,35 \mathrm{~cm}$, proses pembersihan meja yang mudah dilakukan karena menggunakan bahan stainless steel 304 antikarat, memiliki harga kompetitif < Rp. 2.500.000, dan produk awet dan tahan lama 5 tahun sampai 15 tahun yang akan datang.

\section{UCAPAN TERIMA KASIH}

Perjalanan proses Penelitian dan penyusunan makalah ini tentu juga melibatkan beberapa pihak yang membantu. Kami ingin mengucapkan Terima Kasih untuk pihak yang telah membantu penelitian dan penyusunan makalah, diantaranya Ucapan Terima Kasih kepada:

1. LP2S UMI, sebagai Lembaga Penelitian dan Pengembangan Sumberdaya yang memberikan dukungan dalam melaksanakan penelitian hingga penyusunan makalah ini.

2. UPTD Pasar Antang, Sebagai pengurus pasar tradisional yang telah memberikan izin dalam melakukan pengambilan data, dll untuk menyelesaikan penelitian hingga makalah ini selesai.

3. Pedagang Pasar Kolombo, sebagai narasumber untuk memberikan informasi yang berguna.

\section{DAFTAR PUSTAKA}

Anggraeni, M. D., \& Aslamiyah, M. (2018). Gambaran sanitasi Lingkungan di Pasar Blambangan, Banyuwangi. Ilmiah Mahasiswa Kesehatan Masyarkat, 3(4), 1-10. http://ojs.uho.ac.id/index.php/JIMKESMAS/article/viewFile/5206/3870

Çelik, A., Yaman, H., Turan, S., Kara, A., Kara, F., Zhu, B., Qu, X., Tao, Y., Zhu, Z., Dhokia, V., Nassehi, A., Newman, S. T., Zheng, L., Neville, A., Gledhill, A., Johnston, D., Zhang, H., Xu, J. J., Wang, G., ... Dutta, D. (2018). Journal of materials. Journal of Materials Processing Technology.

Haq, A. N., Septinova, D., \& Santosa, P. E. (2015). Kualitas Fisik Daging Dari PAsar Tradisional di Bandar Lampung (The physical of beef from traditional market in Bandar Lampung). Jurnal Ilmiah Peternakan Terpadu, 3(3), 98-103. https://jurnal.fp.unila.ac.id/index.php/JIPT/article/view/832 
Hermin Nugraheni,Tri Wiyatini, I. W. (2018). Kesehatan masyarakat dalam determinan social budaya. In $C V B U D I$ UTAMA.

Hsu, A. (2016). Environmental Performance Index: Global Metrics for the Environment. Yale University, July, 123. https://doi.org/10.13140/RG.2.2.21182.51529

Lestari, T. R. P. (2020). Keamanan Pangan Sebagai Salah Satu Upaya Perlindungan Hak Masyarakat Sebagai Konsumen. Aspirasi: Jurnal Masalah-Masalah Sosial, 11(1), 57-72. https://doi.org/10.46807/aspirasi.v11i1.1523

Mcewen, Craig A., B. S. (2017). Social structure, adversity, toxic stress, and intergenerational poverty: An early childhood model. Annual Review of Sociology, 43, 445-472. https://doi.org/10.1146/annurev-soc-060116-053252

Morales, L. E., \& Higuchi, A. (2018). Is fish worth more than meat? - How consumers' beliefs about health and nutrition affect their willingness to pay more for fish than meat. Food Quality and Preference, 65(November 2017), 101-109. https://doi.org/10.1016/j.foodqual.2017.11.004

Nurcahyo, E. (2018). Pengaturan dan Pengawasan Produk Pangan Olahan Kemasan. Jurnal Magister Hukum Udayana (Udayana Master Law Journal), 7(3), 402. https://doi.org/10.24843/jmhu.2018.v07.i03.p10 